\title{
Stingless bee honeys from Soconusco, Chiapas: a complementary approach
}

\author{
Cristina Espinoza-Toledo ${ }^{1}$, Alfredo Vázquez-Ovando ${ }^{1}$, Rodolfo Torres de los Santos ${ }^{2}$, \\ Alfonso López-García ${ }^{1}$, Victor Albores-Flores ${ }^{1} \&$ Julieta Grajales-Conesa $^{1 *}$ \\ 1. Instituto de Biociencias, Universidad Autónoma de Chiapas. Boulevard Príncipe Akishino s/n. Col. Solidaridad 2000 \\ Tapachula Chiapas CP 30798, Mexico; cristina_30_12@hotmail.com; joalfredovaz@gmail.com; josealoga@hotmail.com; \\ alboresflores@gmail.com; jugrajco79@gmail.com \\ 2. Unidad Académica Multidisciplinaria Mante, Universidad Autónoma de Tamaulipas. Blvd. Enrique Cárdenas González No. \\ 1201 Pte. Col. Jardín, C. P. 89840. Cd. Mante, Tamaulipas, México; rotorres@uat.edu.mx \\ * Correspondence
}

Received 28-I-2018. Corrected 14-VI-2018. Accepted 11-IX-2018.

\begin{abstract}
Stingless bees are located in the tropic areas, and produced a sweet natural substance called pot honey, with different properties and uses. Recently, most studies are focused on characterizing them, in order to contribute to their knowledge and the establishment of quality laws. Thus physicochemical, acceptance and palynological studies were performed in stingless bee honeys from Soconusco, Chiapas, in order to learn and contribute to their knowledge in the Tropics. Nine honey samples were collected from Melipona solani (Ms), M. beecheii $(\mathrm{Mb})$ and Scaptotrigona mexicana $(\mathrm{Sm})$ in different meliponaries. Our results registered physicochemical values that ranged as follow; $\mathrm{pH} 2.8-4.8$, electrical conductivity (EC) $114-1211 \mu \mathrm{S} / \mathrm{cm}$, free acidity 24-100 meq $/ \mathrm{kg}, \mathrm{a}_{\mathrm{w}} 59-71 \mathrm{~g} / 100 \mathrm{~g}$, moisture 35-38 \%, color 0.13-0.75 Pfund scale, reducing sugars 47-71\%, hidroxymethylfurfural (HMF) not determined $-2.72 \mathrm{mg} / 100 \mathrm{~g}$, and diastase activity $1.92-11.22 \mathrm{DN}$. On the other hand, the principal component analysis (PCA) of physicochemical values showed that $86.9 \%$ of the total variability between species was explained by the following parameters $\mathrm{a}_{\mathrm{w}}$, moisture, free acidity, color, $\mathrm{pH}$, sugars and EC. Sm honeys were associated (PCA) with a higher water content, free acidity and darker colors, while Melipona honeys with a sweeter taste and a lower diastase activity; thus honeys could be grouped by genera. The acceptance test showed that $78 \%$ of honeys were preferred, being the SmCa sample in the category "I likely dislike" due to the bitter taste (disapproved by consumers). The melisopalynological results showed that M. beecheii honeys are monofloral with a $45 \%$ of Fabaceae pollen, while Melipona solani and Scaptotrigona mexicana honeys are multi or polyfloral with diferent pollen types; Fabaceae, Melastomataceae, Malvaceae and Asteraceae. From this complementary study we can asume that it is necessary to implicate researchers with producers, so they could have accesss to stingless bee honey analysis and to help them to improve meliponaries management by identifying and introducing stingless bee flora.
\end{abstract}

Key words: physico-chemical; sensory; palynology; tropics.

Espinoza-Toledo, C., Vázquez-Ovando, A., Torres de los Santos, R., López-García, A., AlboresFlores, V., \& Grajales-Conesa J. (2018). Stingless bee honeys from Soconusco, Chiapas: a complementary approach. Revista de Biología Tropical, 66(4), 1536-1546.

Pollination services are provided by certain organisms such as bees, butterflies, moths, flies, beetles, wasps, birds, among others. In this paper, we focus on bees, because they are the most important pollinators at the ecological and commercial level, by pollinating $35 \%$ of flowering crops worldwide (Klein et al., 2007). Therefore, floral resources are important for pollinator's communities, where the abundance of bees is positively associated with the richness of flower species (Potts, Vulliami, Dafni, Ne'eman, \& Wilmer, 2003). Bees also have 
a preference for those plants that provide a better reward, which could result in a greater amount of pollen, nectar, or both (Roubik, 1989). Derived from this some bees produce honey, which presents a variation related to composition, bee species, geographic region, botanic and storage condition (Karabagias, Badeka, Kontakos, Karabournioti, \& Kontominas, 2014). Honey is mainly composed of fructose and glucose, enzymes, proteins, organic acids, minerals, pollen and wax (Sant'Ana, Sousa, Salqueiro, Lorenzon, \& Castro, 2012; Manzanares, García, Galdon, Rodríguez, \& Romero, 2014). This sweet natural substance is not only produced by honeybees, in the tropics, where stingless bees produce it and is called "pot honey", which is appreciated and used as sweetener, and as a treatment for various types of infections (Vit, Medina, \& Enríquez, 2004; Guerrini et al., 2009). Furthermore of physicochemical properties and botanical origin, sensorial studies play an important role to determine consumer acceptance; some authors report that stingless bee honey have different attributes, such as; bitter taste, salty, sweet, and astringent, with citrus scent, floral, fermented, viscosity and a wide variety of colors, registered in honeys from Geotrigona leucogastra, Melipona grandis and Scaptotrigona sp in Ecuador, Tetragonula carbonaria in Australia, and Melipona fasciculata in Brazil (Ferreira, Aires, Barreira \& Estevinho, 2009; Batista de Sousa et al., 2016; Vit, Pedro, Vergara, \& Deliza, 2017). On the other hand, palynological studies allow us to determine botanical and geographic origin of honey in order to control its quality, as well as to recognize the species used for pollen and therefore nectariferous flora of an area (Piedras \& Quiroz, 2007). Nonetheless, there is not enough information to characterize honey, or to establish international standards to promote its trade, and use in pharmaceutical area. There is a need to contribute to its knowledge in all the places where the stingless bees are located, in order to understand their foraging behavior. Thus, this study aimed to characterize stingless bee honeys from the Soconusco region by the following; a) physicochemically analysis, b) acceptance tests and c) palynological origin, in order to learn and contribute to their knowledge.

\section{MATERIALS AND METHODS}

Honey samples: Stingless bee honeys were collected from February to March 2016 at the "Asociación de Meliponicultores del Soconusco S.C. del R. L." located in municipalities of the Soconusco region; Tapachula, Tuxtla-chico and Cacahoatan, South of Mexico. Predominant vegetation is mainly coffe, rambutan, cocoa, marañon, African palm, mango, sesame, tobacco, banana, soybean, citrics and other endemic plants (Instituto Nacional de Estadística y Geografía, 2015). We gathered nine honey samples of the following species: Melipona solani from Trinidad (Msta), San Jeronimo (Mssjb), Izapa (MsIc), Scaptotrigona mexicana from Cacahoatán (Smca), Francisco y Madero (Smfmb), Izapa I (Smic), Izapa II (Smid), M. beecheii from two different places in Tapachula I (Mbta) and Tapachula II (Mbtb). All honeys were collected from three rational hives in each study in order to obtain a mixed sample of the meliponary (100 $\mathrm{ml}$ in total). First pots were opened aseptically with a $20 \mathrm{ml}$ sterile syringes, then stingless bee honeys were kept in sterile labelled flasks and stored in the fridge at $-4{ }^{\circ} \mathrm{C}$ until analysis.

Physicochemical analysis: Phisycochemical parameters were determined by triplicate using AOAC (2001) methods, which included moisture, $\mathrm{pH}$, free acidity, electrical conductivity $(\mathrm{EC})$, water activity $\left(\mathrm{a}_{\mathrm{w}}\right)$, color, reducing sugars, hidroxymethylfurfural (HMF) and diastase activity.

Moisture content was determined by refractometry (AOAC method 919.38) using an ATAGO digital refractometer at $20^{\circ} \mathrm{C}$.

pH and free acidity: $\mathrm{pH}$ was measured according to AOAC (method 962.19, 2006) with an OHAUS pHmeter. Free acidity was determined by the titrimetric method; ten $\mathrm{g}$ of honey was dissolved in $75 \mathrm{ml}$ distilled 
water, and this solution was titrated with $0.05 \mathrm{M} \mathrm{NaOH}$ solution until the $\mathrm{pH}$ reached 8.5. Ten $\mathrm{ml}$ of $0.05 \mathrm{M} \mathrm{NaOH}$ was added immediately, and back-titrated with $0.05 \mathrm{M} \mathrm{HCl}$ solution until the $\mathrm{pH}$ reached 8.3 , to determine the acidity.

Electrical conductivity (EC): Electrical conductivity was determined according to Bogdanov et al. (2004), and it was measured in a $20 \%(\mathrm{w} / \mathrm{v})$ solution of stingless bee honey in distilled water using a digital conductometer.

Water activity $\left(a_{w}\right)$ : Water activity is a gravimetric determination after oven drying at $25^{\circ} \mathrm{C}$, by using an automatic hygrometer (THERMOCONSTANTER NOVASINA T4-2).

Color: According to Pfund scale, color was determined by absorbance measurement at $635 \mathrm{~nm}$ (Montenegro, Avallone, Crazov, \& Aztarbe, 2005), directly on diluted honey samples.

Reducing sugars: Reducing sugars and apparent sucrose were determined by potentiometric titration using the Fehling's test (Lane and Eyon modified method).

Hydroxymethylfurfural (HMF): It was determined by the AOAC method (958.09) where the absorbance of a filtered honey solution, after clarification with carrez solutions and addition of p-toluidine and barbituric acid solutions, is measured at 284 and 336 $\mathrm{nm}$ against a blank in the maximum color intensity (3-4 minutes after the barbituric acid addition) (Bogdanov et al., 2002).

Diastase activity: It was measured photometrically, which was expressed in DN (diastase number), and corresponded to $\mathrm{g}$ starch hydrolysed/100 g honey / h, at pH 5.2 and $\mathrm{T}=40{ }^{\circ} \mathrm{C}$, in Schade units (one diastase unit is the enzyme activity of $1 \mathrm{~g}$ of honey, which can hydrolyse $0.0 \mathrm{I} g$ of starch in one hour at $40^{\circ} \mathrm{C}$ ) (Vit \& Pulcini, 1996).
Acceptance test: This test was performed with a panel of 80 untrained judges; students from "Instituto de Biociencias" between 18-22 years old. They were provided with $1 \mathrm{ml}$ of honey in small transparent containers. This test was performed during $9 \mathrm{~d}$ (a tasting per $\mathrm{d}$ ) from 8:00 - 9:00; once they tasted the honey, they were asked to express the acceptance level by a facial hedonistic scale format with 7 categories, where $1=$ I really like and $7=$ really don't like (Singh-Ackbaralil \& Maharaj, 2014).

Palynological analysis: Stingless bee honeys were qualitatively and quantitatively pollen analyzed, by using the acetolysis technique (Louveaux, Maurizio, \& Vorwohl 1978). The sediment was fixed in glycerin gelatin on slides (three slides per sample). The pollen grains were observed under the 100X target along with an image analyzer. For pollen identification we used reference manuals (Palacios, Ludlow, \& Villanueva, 1991; Roubik \& Moreno, 1991; Martínez et al., 1993). Pollen grains were classified according to Louveaux et al. (1978) as predominant ( $>45 \%$ of the grains counted in a sample), secondary (16-45 $\%$ ), important minor pollen (3-15\%) and minor pollen $(\leq 3 \%)$.

Statistical analysis: An analysis of variance (ANOVA) was used to determine physicochemical differences between the stingless bee honey, followed by a principal component analysis (PCA) to explain the association with the physico-chemical parameters using InfoStat software (Di Rienzo et al., 2015). For the acceptance test, a non-parametric analysis of variance was performed using the KruskallWallis test with the INFOSTAT software (Di Rienzo et al., 2015). In the palynological analysis the samples of honey were analyzed with Shannon-Wiener and Pielou indexes by using PAST software (Hammer, Harper, \& Ryan, 2001). 


\section{RESULTS}

Physical-chemical analysis: We observed differences in stingless bee honeys from different species and origin (Table 1). $\mathrm{pH}$ values ranged between 2.8-4.8, which showed significant differences $(\mathrm{P}<0.05)$. In contrast, the electrical conductivity (EC) values varied between 114-1211 $\mu \mathrm{S} / \mathrm{cm}$, free acidity oscillated in the range of $24-100 \mathrm{meq} / \mathrm{kg}$. The $\mathrm{a}_{\mathrm{w}}$ varied between $59-71 \mathrm{~g} / 100 \mathrm{~g}$, and showed significant differences $(\mathrm{P}<0.05)$. The moisture content was in the range of $35-38 \%$. With regard to color, which is the first sensory property perceived by consumers and that could influence acceptance and / or rejection, honey samples registered variation from $0.13-0.75$ Pfund scale, where honeys varied from dark white-amber color, showing significant differences between the samples $(\mathrm{P}<0.05)$. The reducing sugars showed values of 47-71 \%, with significant differences, in this study the HMF content in fresh honeys is low. The samples in the work showed HMF values below $2.72 \mathrm{mg} / 100 \mathrm{~g}$, the samples MsTa, SmCa and $\mathrm{MbTb}$, showed absence of this compound. On the other hand, diastase activity is also used as marker for the freshness of honeys because its amount decreases in old or heated honeys. The results show ranges of (1.92-11.22 DN), the samples did not present significant differences $(P>0.05)$, thus showing the presence of the enzyme in honey samples.

Acceptance analysis: The acceptance results are shown in Fig. 1, where seven of the evaluated honeys were accepted by consumers in categories 2 (I like a lot) 3 (I lighthly like). In addition, these honeys had greater acceptability for the panelists. In contrast the SmCa sample registered the category 5 (I lightly dislike) with a $41 \%$, followed by the SmFMb simple with the category 4 /nor like nor dislike), which reported a bitter taste.

Palynological analysis: Our results showed differences in diversity and foraging uniformity; the diversity index $(\mathrm{H})$ showed

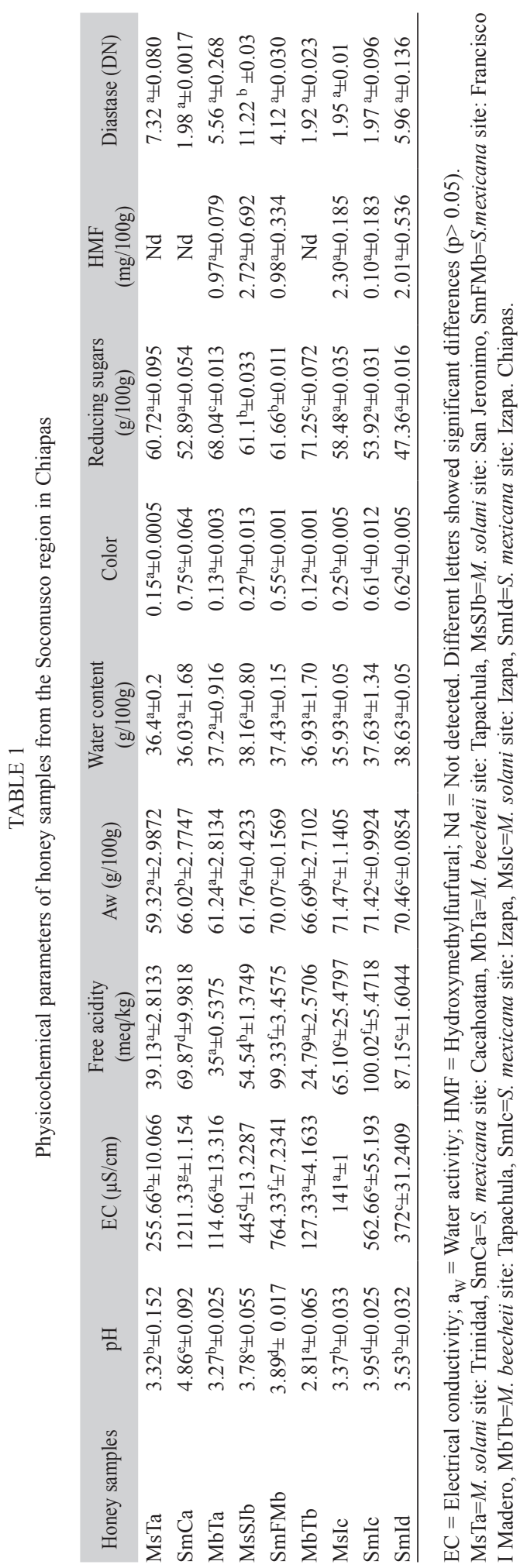




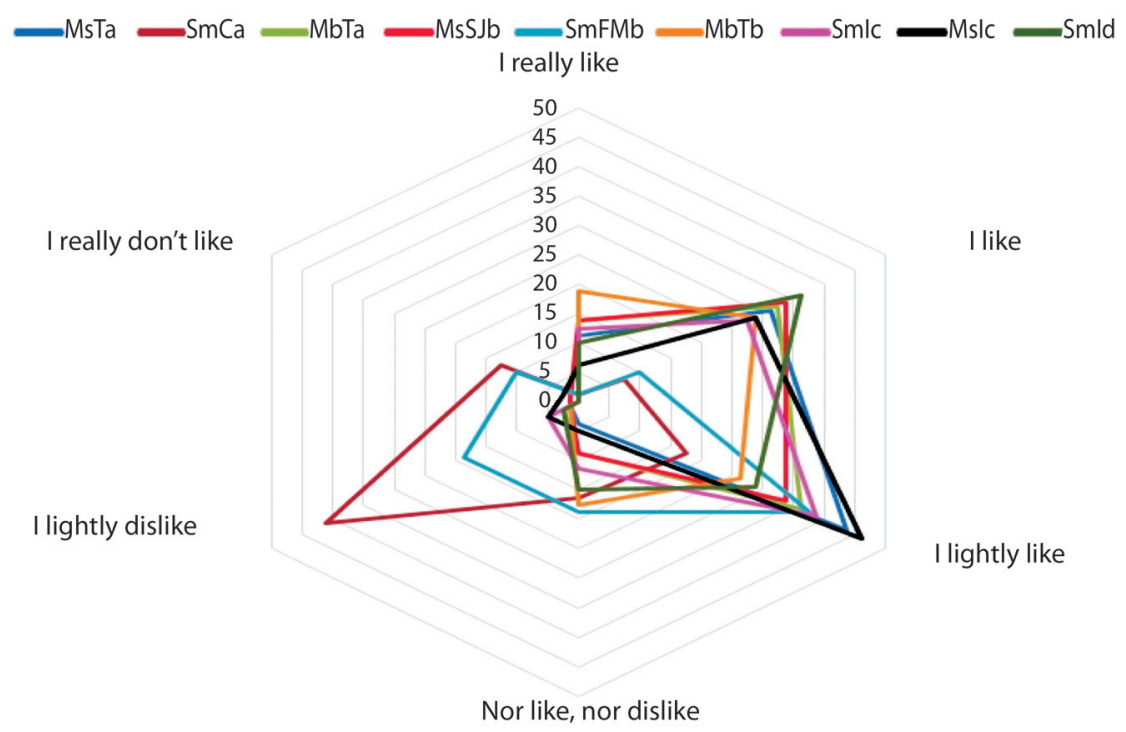

Fig. 1. Preference test for stingless bee honeys; $\mathrm{MsTa}=M$. solani site: Trinidad, $\mathrm{SmCa}=S$. mexicana site: Cacahoatan, $\mathrm{MbTa}=M$. beecheii site: Tapachula, $\mathrm{MsSJb}=M$. solani site: San Jeronimo, $\mathrm{SmFMb}=S$. mexicana site: Francisco I Madero, $\mathrm{MbTb}=M$. beecheii site: Tapachula, $\mathrm{SmIc}=S$. mexicana site: Izapa, MsIc $=M$. solani site: Izapa, $\mathrm{SmId}=S$. mexicana site: Izapa. The categories range from 1 (I really like) to 6 (I really don't like).

values of 1.10-2.36 with a uniformity distribution of species in each sample, meanwhile the Pielou index (0.40-0.75) explained that when the dominance of the species is higher over the others, the value will tend more strongly toward zero, indicating an oligolectic behavior from bees. On the other hand, the Jaccard index showed the similarity between each sample of honey in terms of the presence / absence of botanical species, where four groups are observed, among them the first and last, since there is a dissimilarity between these honey samples (MsTa, MbTb and MbTa). The frequencies of the pollen grains present in the honeys are shown in Fig. 2 and the different views of the main pollen families in Fig. 3. Honey samples of $M$. beecheii recorded a percentage higher than $45 \%$ of pollen grains corresponding to the Fabaceae family, showing monofloral honey. In relation to the honeys of $S$. mexicana the secondary pollen spectrum of the samples corresponded to the families Melastomataceae, Malvaceae, Asteraceae and Fabaceae in 25, 28, 5, 15 and $18 \% ; 12 \%$
$0.66 \%$ and $0.33 \%$ frequency, these samples being poly or multifloral honeys.

Quality indicators: The principal component analysis (PCA) represents $86.9 \%$ of the total variability between the species with the parameters analyzed (Fig. 4), the MbTa, MbTb and MsTa honeys are negatively correlated

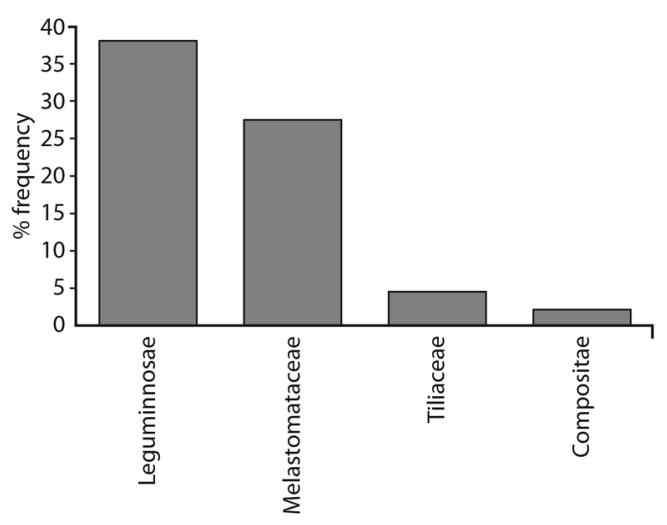

Fig. 2. Relative abundance of pollen types observed in stingless bee honeys from Soconusco, region. 

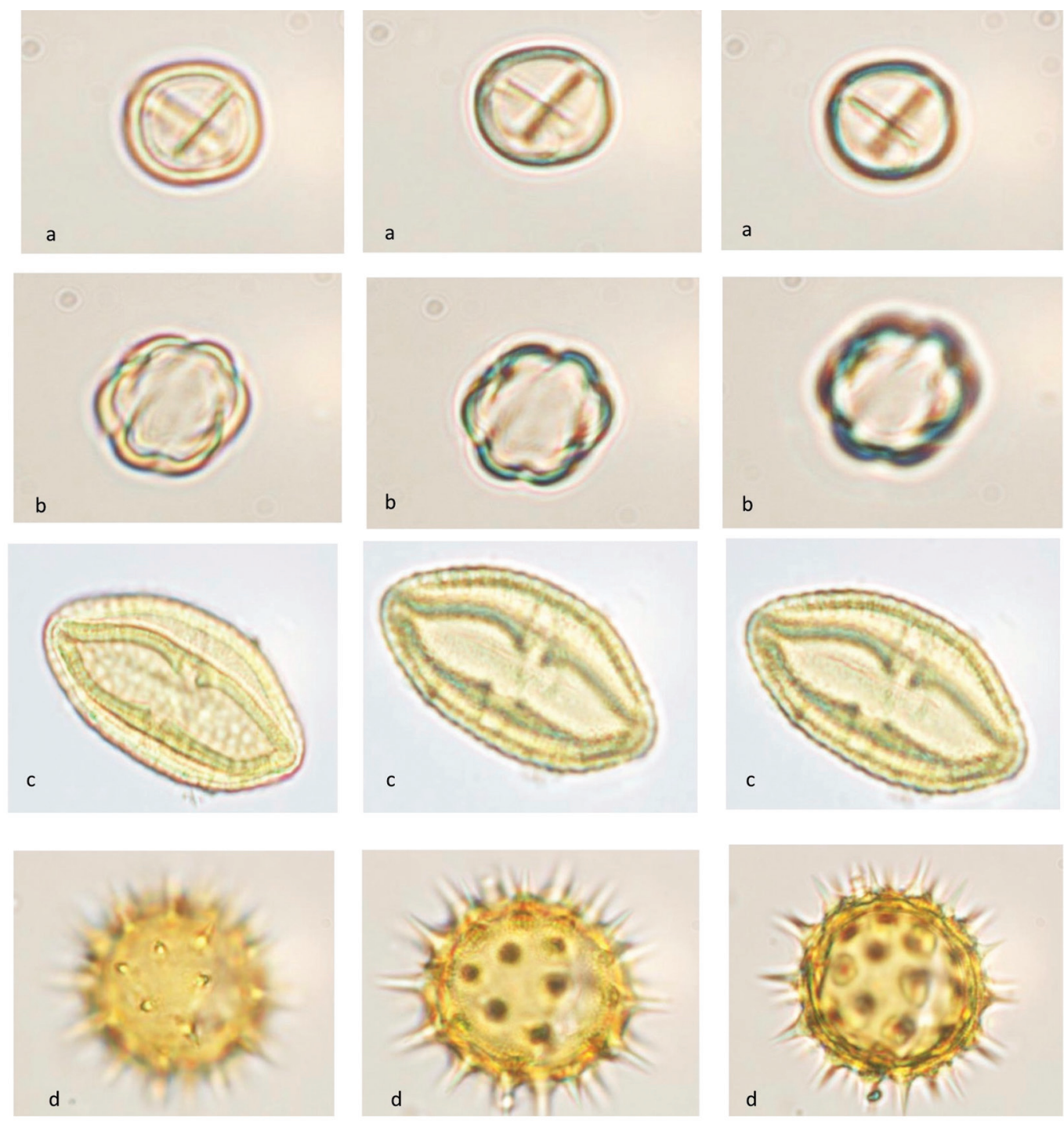

Fig. 3. Different views of the pollen grains observed in stingless bee honeys from Soconusco, Chiapas. A) Fabaceae, B) Melastomataceae, C) Malvaceae, D) Asteraceae.

with the reducing sugars variable, which was higher (>60\%), the MsIc sample was related to HMF being in the same way one of the higher values of this compound $(2.30 \mathrm{mg} / 100$ $\mathrm{g}$ ), in the MsSJb sample the diastase activity registered the highest enzymatic activity, the $\mathrm{SmCa}$ honey is closely related to the $\mathrm{pH}$ and EC variables; the samples SmId, SmIc and $\mathrm{SmFMb}$ have a positive correlation with the variables HMF, $\mathrm{a}_{\mathrm{w}}$, humidity, free acidity and color, with higher moisture, more acidic, with water activity superior to samples of Meliponas, and were the darkest ones. In addition to the correlations between the samples and the variables there is also a clear separation of the genera Melipona and Scaptotrigona.

Based on the results obtained in the PCA, the quality indicators were obtained, which showed the ranges of each parameter that these species must present in the Soconusco area of 


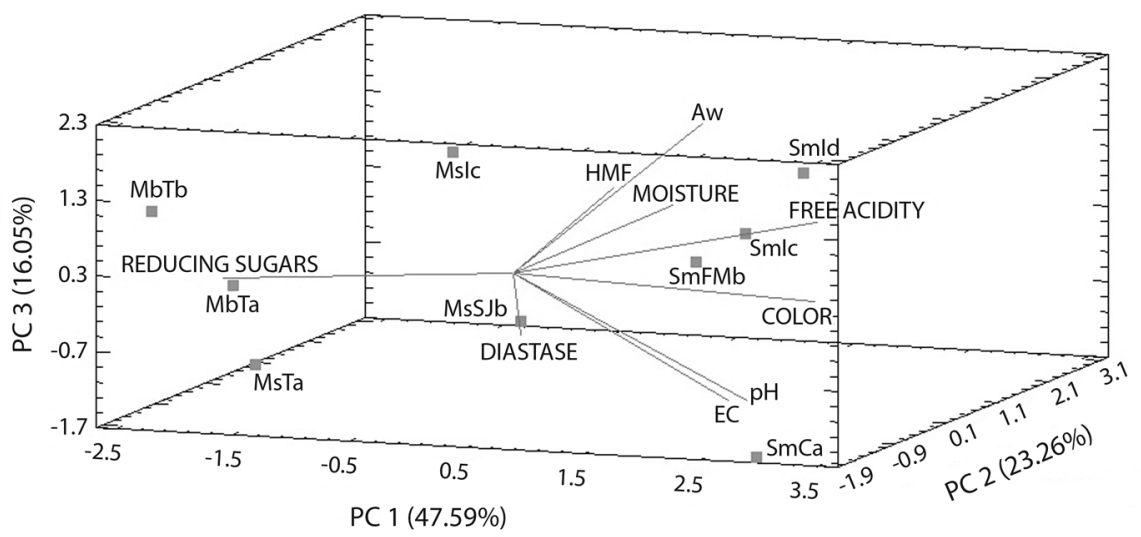

Fig. 4. Principal Component Analysis of the physicochemical properties of stingless bee honeys analyzed.

Chiapas, where honeys can be grouped as follow, in Scaptotrigona honeys humidity values are higher than $30 \%, \mathrm{a}_{\mathrm{w}}$ and free acidity is higher than $60 \mathrm{~g} / 100 \mathrm{~g}$, $\mathrm{pH}$ between 2.8 and 4.8, relatively low HMF less than $2 \mathrm{mg} / 100 \mathrm{~g}$, dark amber honeys. Melipona honeys showed higher sugar ranges (> $60 \%)$ and lower enzymatic activity.

\section{DISCUSSION}

The parameters of $\mathrm{pH}$ agreed with the parameters proposed by the International Honey Commission (IHC) for Melipona and Scaptotrigona genera (Vit et al., 2004). In contrast, our EC values are above the required by the Codex Alimentarius $(800 \mu \mathrm{S} / \mathrm{cm})$; some studies reported EC values between 300-670 $\mu \mathrm{S} / \mathrm{cm}$ (Batista de Sousa et al., 2016). However, in some honeys from Brazil, Biluca, Braghini, Gonzaga, Costa, \& Fett (2016) have registered different values; $1340 \mu \mathrm{S} / \mathrm{cm}$ for Tetragonisca angustula, $1010 \mu \mathrm{S} / \mathrm{cm}$ for Tetragona clavipens and $830 \mu \mathrm{S} / \mathrm{cm}$ for M. quadriasciata (Biluca et al., 2016). These differences could be related to bee species, floral sources visited, due to there are similar results reported when floral source is similar (Almeida-Muradian et al., 2013). On the other hand, when comparing our free acidity results with previous studies in the genera: Homotrigone, Lepidotrigone, Lisotrigone,
Tetragonilla, Tetragonula and Tetrigona from Thailand, we can observe that our honeys agreed with the values previously reported 44-121 meq/kg (Chuttong, Chanbang, Sringarm, \& Burgett, 2016), similar to the registered for stingless bees from South America with 139 $\mathrm{meq} / \mathrm{kg}$ (Biluca et al., 2016). Higher values in fresh honeys could be related to organic acid from nectar or the floral source. The results of $a_{w}$ compared with other studies are higher than those reported by Batista de Sousa et al. (2016) 23.9-28.9 g/100 g. The moisture content of these honeys is higher than the proposed by Vit et al. (2004) (maximum of $30.0 \%$ ), some studies on honey of Plebeia sp., presented moisture values from $30.26 \%$, (Dardón \& Enríquez, 2008). With regard to color, considered as the first sensory property perceived by consumers, could influence the acceptance and / or rejection of the product. Studies performed with stingless bee honeys have reported color from light, amber and brown (Finola, Lasagno, \& Marioli, 2007; Batista de Sousa et al., 2016), which agreed with our results. On the other hand, the reducing sugars values are not only within the ranges proposed by the IHC for these same genera (Vit et al., 2004), but also correspond to the values observed in other studies (Andrade et al., 1999; Rodriguez, Ferrer, Ferrer, \& 2004; Kucuk et al., 2007). The HMF content in higher concentration is 
observed in old honeys and in honey that has been heated, stored in non-adequate conditions, or adulterated with invert sugar or syrup. The samples MsTa, SmCa and MbTb in the study showed absence of this compound which contrasted with the limit established by Vit et al. (2004), which suggested $40 \mathrm{mg} / \mathrm{kg}$, as well as the absent of this value in other studies (Vit, 2008; Habib, Al Meqbali, Kamal, Souka, \& Ibrahim, 2014). Batista de Sousa et al. (2016) have reported the absent of HMF in monofloral honeys from the genus Melipona in different regions from Brazil, and Biluca et al. (2016) have registered HMF values lower than 0.31 $\mathrm{mg} / \mathrm{L}$ (Biluca et al., 2016). The diastase activity is also used as marker for the freshness of honeys because its amount decreases in old or heated honeys. According to the Honey Quality and International Regulatory Standards, from the International Honey Commission, the diastase activity must not be less than or equal to 8 , expressed as diastase number (DN), but the Codex Alimentarius (FAO, 2001) has established the minimum diastase activity value of 3 , for honeys with natural low enzyme content. The low content of Diastase was only present in four samples of honey, but the Codex Alimentarius mentions that HMF in honeys with low content of this enzyme is not higher than $15 \mathrm{mg} / \mathrm{kg}$, therefore the content of HMF in these were very low therefore these quality honeys are considered. The values of the parameters analyzed in this study vary due to different factors such as botanical origin, geographical origin, climatic conditions, bee species, storage, date of harvest, as well as the presence of organic acids, minerals, proteins, polyols, gluconic acid, some antioxidants, such as carotenoids and flavonoids (Terrab, Diez, \& Heredia, 2003; Acquarone, Buera, \& Elizalde, 2007; Baltrusaityte, Venskutonis, \& Ceksteryte, 2007; Silvano, Varela, Palacio, Ruffunengo, \& Yamul, 2014).

On the other hand, our results agreed with the reported by Deliza \& Vit (2013), who found that $S$. mexicana honeys showed fewer acceptances due to bitter taste. Other unusual descriptors considered as unpleasant are sour/ acid/moldy/alcoholic/urine/rape/wine, gave the lowest acceptance values, and have been reported in M. scutelaris honeys (Ferreira et al., 2009). In a similar way to the physicochemical characteristics, the preference of honey is related to bee species, botanical origin, maturation time and storage conditions (Sousa et al., 2016). Sensorial characteristics are also related to physico-chemical properties (Habib et al., 2014) and in our study we observed that honeys well accepted $(\mathrm{MbTb})$ registered the highest reducing sugar value, similar to the observed by Ferrerira et al. (2009). It has also observed that monofloral honeys showed a better acceptance and registered higher reducing sugar values (Sousa et al., 2016). Thus, the most important aspects that influence the preference or acceptance of consumers and therefore the commercialization of honey is the botanical and geographical origin (Estevinho, Feás, Seijas, \& Vázquez-Tato, 2012).

Based on our results, we observed similarity with Roubik (1996), who registered pollen dominance of Leguminosae family in Melipona honeys; in this sense, Almeida-Muradian et al. (2013) in M. subnitida honeys, predominant pollen of Alternanthera sp and Mimosa verrucosa, belonging the last one to the Fabaceae family. In relation to $S$. mexicana honeys, Ramírez-Arriaga and Martínez-Hernández (2007) indicated that S. mexicana has very particular preferences for Melastomataceae and Malvaceae also found in this study, as well as Asteraceae and Piperaceae.

Once we compared our results with Vit, Persano, Marano, \& Salas de Mejías (1998) results, we agreed, by founding a separation within Trigonas and Meliponas. The PCA showed that the Scaptotrigona honeys are positively correlated with the variables $a_{w}$, humidity, HMF, free acidity, color, $\mathrm{pH}$ and $\mathrm{CE}$ and the reducing sugars with the Melipona samples, however we could infer that the most important parameters to analyze and establish quality indicates are humidity, HMF and diastase activity. The acceptance test showed that all the honeys were prefered by the consumers except for the SmCa sample. Based on the 
palynological analysis $M$. beecheii honeys are monofloral and those of $M$. solani and the $S$. mexicana honey are honey multifloral. These studies at the physico-chemical, sensorial and palynological level could help us to preserve native bees, besides we can implicate researchers with producers, so they could have access to stingless bee honey analysis. On the other hand palynological studies will help producers to improve meliponaries management, in order to identify and introduce stingless bee flora.

\section{ACKNOWLEDGMENTS}

The realization of this work involved the support of several people who we thank. Mainly Miguel Ángel Guzmán Díaz in the sampling of stingless bee honey, as well as the association of Meliponicultores del Soconusco S. C. del R. L.

\section{RESUMEN}

Mieles de abejas sin aguijón del Soconusco, Chiapas: enfoque complementario. En las regiones tropicales se ubican las abejas sin aguijón, las cuales producen una sustancia dulce denominada miel de cántaro con propiedades y usos diferentes a los de las abejas melíferas (Apis mellifera). Actualmente, se han desarrollado diversos trabajos enfocados a su caracterización, con la finalidad de contribuir con su conocimiento y el establecimiento de estándares de calidad. En este estudio se realizaron estudios fisicoquímicos, de aceptación y palinológicos en mieles de abejas sin aguijón de Soconusco, Chiapas. Se recolectaron nueve muestras de miel de las siguientes especies: Melipona solani (Ms), M. beecheii (Mb) y Scaptotrigona mexicana $(\mathrm{Sm})$ en diferentes meliponarios. Nuestros resultados registraron valores fisicoquímicos que variaron de la siguiente manera: $\mathrm{pH} 2.8-4.8$, conductividad eléctrica (CE) 114-1 $211 \mu \mathrm{S} / \mathrm{cm}$, acidez libre 24-100 meq $/ \mathrm{kg}$, aw 59-71 g/100 g, humedad 35-38 \%, color 0.13-0.75 escala Pfund, azúcares reductores $47-71 \%$, hidroximetilfurfural (HMF) no determinado $-2.72 \mathrm{mg} / 100 \mathrm{~g}$, y actividad de la días-tasa 1.92-11.22 ND. Por otro lado, el análisis del componente principal (PCA) de los valores fisicoquímicos mostró que el $86.9 \%$ de la variabilidad total entre las especies se explica por los siguientes parámetros: aw, humedad, acidez libre, color, pH, azúcares y CE. Las mieles de Sm (PCA) se asociaron con un mayor contenido de agua, acidez libre y colores más oscuros, mientras que las mieles de Melipona con un sabor más dulce y una actividad de días-tasa más baja; por lo tanto, las mieles podrían agruparse por géneros.
La prueba de aceptación mostró que el $78 \%$ de las mieles eran preferidas, siendo la muestra de $\mathrm{SmCa}$ en la categoría "Probablemente no me gusta" debido al sabor amargo (desaprobado por los consumidores). Los resultados melisopalinológicos mostraron que las mieles de $M$. beecheii son monoflorales con un $45 \%$ de polen de Fabaceae, mientras que las mieles de $M$. solani y $S$. mexicana son multi o poliflorales con diferentes tipos de polen: Fabaceae, Melastomataceae, Malvaceae y Asteraceae. De este estudio complementario observamos que se requiere poner en contacto a investigadores y productores, para que el acceso a los análisis de las mieles de abejas sin aguijón sea posible, y así mismo se pueda ayudar con el mejoramiento del manejo de los melionarios al momento de identificar e introducir la flora preferida por las abejas sin aguijón.

Palabras clave: físico-químicos; sensorial; palinología; trópicos.

\section{REFERENCES}

Acquarone, C., Buera, P., \& Elizalde, B. (2007). Pattern of $\mathrm{pH}$ and electrical conductivity upon honey dilution as a complementary tool for discriminating geographical origin of honeys. Food Chemistry, 101, 695-703.

Almeida-Muradian, L., Stramm, K., Horita, A., Barth, O., De Freitas, A., \& Estevinho, L. (2013). Comparative study of the physicochemical and palynological characteristics of honey from Melipona subnitida and Apis mellifera. International Journal of Food Science and Technology, 48, 1698-1706.

Andrade, P. B., Amaral, M. T., Isabel, P., Carvalho, J. C. M. F., Seabra, R. M., \& Cunha, A. P. (1999). Physicochemical attributes and pollen spectrum of Portuguese heather honeys. Food Chemistry, 66, 503-510.

Association of Official Analytical Chemists (AOAC). (2001). Methods of analysis. Washington, D. C.: AOAC.

Baltrusaityte, V., Venskutonis, P. R., \& Ceksteryte, V. (2007). Radical scavenging activity of different floral origin honey and beebread phenolic extracts. Food Chemistry, 101, 502-514.

Batista de Sousa, J. M., Leite de Souza, E., Marques, G., Toledo, M., Gullón, B., Pintado, M., \& Magnani, M. (2016). Sugar profile, physicochemical and sensory aspects of monofloral honeys produced by different stingless bee species in Brazilian semi-arid region. LWT Food Science and Technology, 65, 645-651.

Biluca, F. C., Braghini, F., Gonzaga, L. V., Costa, A. C. O., $\&$ Fett, R. (2016). Physicochemical profiles, minerals and bioactive compounds of stingless bee honey (Meliponinae). Journal of Food Composition and Analysis, 50, 61-69. 
Bogdanov, S., Lullman, C., Martin, P., Werner, V., Russmann, H., Russmann, G., ... Vit., P. (2004) Honey quality, methods of analysis and international regulatory standards: Review of the work of the international honey commission. Bee World, 80, 61-69.

Chuttong, B., Chanbang, Y., Sringarm, K., \& Burgett, B. (2016). Physicochemical profiles of stingless bee (Apidae: Meliponini) honey from South East Asia (Thailand). Food Chemistry, 192, 149-155.

FAO. 2001. Food and Agriculture Organization of the United Nations. Revised codex standard for honey (No. CODEX STAN 12-1981). Available from: www.fao. org/input/download/standards/310/cxs_012e.pdf

Dardón, M. J., \& Enriquez E. (2008). Caracterización fisicoquímica y antimicrobiana de la miel de nueve especies de abejas sin aguijón (Meliponini) de Guatemala. Interciencia, 33, 916-922.

Deliza, R., \& Vit, P. (2013). Sensory evaluation of stingless bee pot honey. In P. Vit, S. Pedro, \& Roubik, D. (Eds), Pot-Honey: A legacy of stingless bees (pp. 349-361). Springer New York.

Di Rienzo, J. A., Casanoves, F., Balzarini, M. G., González, L., Tablada, M., \& Robledo, Y. C. (2015). InfoStat versión 2014. Grupo InfoStat, FCA, Universidad Nacional de Córdoba, Argentina. Recuperado de http://www.infostat.com.ar

Estevinho, L., Feás, X., Seijas, J., \& Vázquez-Tato, M. (2012). Organic honey from Tras-Os-Montes region (Portugal): chemical, palynological, microbiological and bioactive compounds characterization. Food and Chemical Toxicology, 50, 258-264.

FAO. (2001). Food and Agriculture Organization of the United Nations. Revised codex standard for honey (No. CODEX STAN 12-1981). Recuperado de www. fao.org/input/download/standards/310/cxs_012e.pdf

FAO. (2001). Food and Agriculture Organization of the United Nations. Revised codex standard for honey (No. CODEX STAN 12-1981). Available from: www. fao.org/input/download/standards/310/cxs 012e.pdf.

Ferreira, I. C. F. R., Aires, E., Barreira, J. C. M., \& Estevinho, L. M. (2009). Antioxidant activity of Portuguese honey samples: different contributions of the entire honey and phenolic extract. Food Chemistry, 114, $1438-1443$

Finola, M. S., Lasagno, M. C., \& Marioli, J. M. (2007). Microbiological and chemical characterization of honeys from central Argentina. Food Chemistry, 100, $1649-1653$

Guerrini, A., Bruni, R., Maietti, S., Poli, F., Rossi, D., Paganetto, G., ... Sacchetti, G. (2009). Ecuadorian stingless bee (Meliponinae) honey: a chemical and functional profile of an ancient health product. Food Chemistry, 114, 1413-1420.
Habib, H., Al Meqbali, F., Kamal, H., Souka, U., \& Ibrahim, W. (2014). Physicochemical and biochemical properties of honeys from arid regions. Food Chemistry, 153, 35-43.

Hammer, Ø., Harper, D. A. T., \& Ryan, P. D. (2001). PAST: Paleontological statistics software package for education and data analysis. Palaeontologia Electronica, 4 (1), 9. Recuperado de: http://palaeoelectronica. org/2001_1/past/issue1_01.htm

Instituto Nacional de Estadística y Geografía. (2015). Anuario Estadístico y Geográfico de Chiapas. Recuperado de http://www.inegi.org.mx/

Karabagias, I. K., Badeka, A. V., Kontakos, S., Karabournioti, S., \& Kontominas, M. G. (2014). Botanical discrimination of Greek unifloral honeys with physicochemical and chemometric analyses. Food Chemistry, 165, 181-190.

Klein, A., Vaissière, B., Cane, J., Steffan-Dewenter, I., Cunningham, S., Kremen, C., \& Tschantke, T. (2007). Importance of pollinators in changing landscapes for world crops. Proceedings of the Royal Society B, 274, 303-313.

Kucuk, M., Kolaylı, S., Karaoglu, S., Ulusoy, E., Baltac, C., \& Candan, F. (2007). Biological activities and chemical composition of three honeys of different types from Anatolia. Food Chemistry, 100, 526-534.

Louveaux, J., Maurizio, A., \& G. Vorwohl. (1978). Methods of Melissopalinology. Bee World, 59, 39-157.

Manzanares, A. B., García, Z. H. B., Galdon, R., Rodríguez, E. R., \& Romero, C. D. (2014). Physicochemical characteristics of minor monofloral honeys from Tenerife, Spain. LWT Food Science and Technology, $55,572-578$.

Martínez-Hernández, E., Cuadriello-Aguilar, J., TéllezValdez, O., Ramírez-Arriaga, E., Sosa-Nájera, M., Medina-Camacho, M., \& Lozano-García, M. (1993). Atlas de las plantas y el polen utilizados por las cinco especies principales de abejas productoras de miel de la región del Tacaná, Chiapas, México. México, D. F.: Editorial Universidad Nacional Autónoma de México.

Montenegro, S., Avallone, C., Crazov, A., \& Aztarbe, M. (2005). Variación del color en miel de abejas (Apis mellifera). Reunión de Comunicaciones científicas y tecnológicas de la Universidad Nacional del Nordeste. Recuperado de http://studylib.es/doc/4728084/t-070

Palacios, R., Ludlow-Wiechers B., \& Villanueva, R. 1991. Flora palinológica de la Reserva de la Biosfera de Sian' Ka'an, Quintana Roo, México. Quintana Roo, México: Editorial Centro de Investigaciones de Quintana Roo. 
Piedras, B., \& D. Quiroz. (2007). Estudio melisopalinológico de dos mieles de la porción sur del Valle de México. Polibotánica, 23, 57-75.

Potts, S., Vulliami, B., Dafni, A., Ne`eman, G., \& Wilmer, P. (2003). Linking bees and flowers: How do floral communities structure pollinator communities? Eco$\log y, 84,2628-2642$.

Ramírez-Arriaga, E., \& Martínez-Hernández, E. 2007. Melitopalynological Characterization of Scaptotrigona mexicana Guérin (Apidae: Meliponini) and Apis mellifera L. (Apidae:Apini) Honey Samples in Northern Puebla State, Mexico. Journal of the Kansas Entomological Society, 80, 377-391.

Rodriguez, G. O., Ferrer, B. S., Ferrer, A., \& Rodriguez, B. (2004). Characterization of honey produced in Venezuela. Food Chemistry, 84, 499-502.

Roubik, D. W. (1989). Ecology and natural history of tropical bees. New York: Cambridge University Press.

Roubik, D. W. (1996). Measuring the meaning of honey bees. In A. Matheson, S. L. Buchmann, C. O'Toole, P. Westrich, \& I. H. Williams (Eds), The conservation of bees (pp. 163-172). London: Academic Press.

Roubik, D. W., \& Moreno, J. E. (1991). Pollen and spores of Barro Colorado Island. St. Louis: Missouri Botanical Garden.

Sant'Ana, L. D., Sousa, J. P., Salqueiro, F. B., Lorenzon, M. C., \& Castro, R. N. (2012). Characterization of monofloral honeys with multivariate analysis of their chemical profile and antioxidant activity. Journal of Food Science, 77, 135-140.

Silvano, M., Varela, M., Palacio, M., Ruffunengo, S., \& Yamul, D. (2014). Physicochemical parameters and sensory properties of honeys from Buenos Aires region. Food Chemistry, 152, 500-507.

Singh-Ackbarali, D., \& Maharaj, R. (2014). Sensory evaluation as a tool in determining acceptability of innovative products developed by undergraduate students in food science and technology at the University of Trinidad and Tobago. Journal of Curriculum and Teaching, 3, 10-27.

Terrab, A., Diez, M. J., \& Heredia, F. J. (2003). Palynological, physico-chemical and colour characterisation of Moroccan honeys: II. Orange (Citrus sp.) honey. International Journal of Food Science and Technology, 38, 387-394.

Vit, P. (2008). Review: valorization honey of stingless bees (Meliponini). Brazilian Journal of Pharmaceutical Science, 50, 20-28.

Vit, P., Medina, M., \& Enríquez, E. (2004). Quality standards for medicinal uses of Meliponinae honey in Guatemala, Mexico and Venezuela. Bee World, $85,2-4$.

Vit, P., Pedro, S., Vergara, C., \& Deliza, R. (2017). Ecuadorian honey types described by Kichwa community in Rio Chico, Pastaza province Ecuador using freechoice profiling. Revista Brasileira de Farmacognosia, 27, 384-387.

Vit, P., Persano, L., Marano, M. L., \& Salas de Mejías, E. (1998). Venezuelan stingless bee honeys characterised by multivariate analysis of compositional factors. Apidologie, 29, 377-389.

Vit, P., \& Pulcini, P. (1996). Diastase and invertase activities in Meliponini and Trigonini honeys from Venezuela. Journal of Apicultural Research, 35, 57-62. 